\title{
Effectiveness of HR Policy in ITES at Chennai
}

\author{
D. K. Hemamalini, G. Sundharavadivel
}

\begin{abstract}
All policies are based on the recruitment, selection, and separation of employees are included in this function. The HR policies define how the organization wants to utilise the key aspects of people management. As guidelines it aim is to ensure that any HR issues are deal with consistently in accordance with values and vision of an organization and in line with certain defined principles. Human resource policy helps to the attainment of business strategy of the organization. Therefore, human resource policy is important for the survival, growth and improvement of the organizations. This article majorly study on the factors affecting the HR policies followed at the ITES industries at Chennai.
\end{abstract}

Keywords : About four key words or phrases in alphabetical order, separated by commas.

\section{INTRODUCTION}

Information technology (ITES) industry in India is comparatively a emerging industry. The Indian software industry can be considered one of the 20th century's most surprising economic improvement, with India apparently coming from nowhere to become a major supplier of manpower and software development service to the US and the remaining of the development world. India possessed a surfeit of scientifically trained talent whose skills were easily adaptable and flexible to the needs of the software industry. The story on the India information technology (ITES) industry is characterized by the evolution of capabilities.

\section{NEED FOR THE STUDY}

Human resource policy implies to build and sustain a manpower resource conducive environment for workforce for maintaining organizational sustainability.

Human resource policy act as a guideline for managerial decision-making on all human resource issues.

Human resource policy used to bring in and maintain "

equity" without any discrimination within the organization and build sensible relationship at all levels.

Human resource policy is useful in achieving the business competitive advantages of the organization effectively.

Human resource policy helps the management in enhancing its human resources. This does not make any problem or ambiguity as all the decisions are taken in the lights of

Revised Manuscript Received on December 05, 2019.

* Correspondence Author

D. K. Hemamalini*, Research Scholar, Department of Adult and Continuing Education, University of Madras, Chennai, India. Email: dk.hemi@gmail.com

Dr. G. Sundharavadivel, Professor and Research Supervisor, Department of Adult and Continuing Education,University of Madras, Chennai, India. predetermined human resource policy. Human resource policy guide to extend effectively the " control" perform of the organisation.

Human resource policy encourages and expects the commitment of the manpower through its various decisions making within the organization.

\section{SCOPE OF THE STUDY}

\section{A. Employment}

Employment policies should provide clear guidelines on the following points:

- Minimum hiring qualification.

- Basis (length of service or efficiency) to be followed in discharging an employee.

- $\quad$ Preferred source of recruitment.

- Reservation of seats for schedule castes, schedule tribes, handicapped persons and ex-servicemen.

- Layoff and retiring.

\section{B. Training and Development}

- Attitudes toward training

- Objectives of training.

- Basis of training.

- Orientation of new candidates.

- Opportunities for career advancement.

C. Transfers and Promotions

- Rational of transfers

- Periodicity of transfer

- Relative weightage to seniority and merit in promotion

- Seniority rights

- Channels of promotion

\section{Working Conditions}

- Working hours, Numbers and duration of rest intervals, Overtime work, Safety rules and regulations, Shift work, Leave rules

\section{E. Employee Services and Welfare}

- Types of services- housing, transportation, medical facilities, Education of children, group insurance, credit facilities, purchase of company' s products at discount, social security etc.

- Financing of employee services

- Incentives to motivate 


\section{F. Industrial Relations}

- Handling of grievances

- Recognition of trade union

- Suggestions schemes

- Discipline and conduct rules

\section{OBJECTIVES OF THE STUDY}

\section{Primary Objective}

- To measure the Effectiveness of HR policies in ITES companies at Chennai

\section{Secondary Objectives}

- To find out the employees are aware the policies followed in the organization.

- To analyze the type of HR policies followed in the organization.
○ Employment policies
- Training and Development
- Transfers and promotions
- Working conditions
○ Employee services and welfare
- Industrial Relation

- To find out the employee suggestion to improve the HR policies.

\section{LIMITATIONS OF THE STUDY}

- Time was one of the major constraints as the period of the study was for 3 months.

- Some of the respondents are unwilling to respond to the questionnaire because of their heavy work schedule.

- The sample size collected for the research is only 110 samples so the accurate results cannot be delivered.

- The respondent's options may be biased.

\section{RESEARCH METHODOLOGY}

The Area of study is Human Resource Management and the study is on Effectiveness of HR policies in ITES companies at Chennai. The sampling method adopted for the study is Convenience Sampling. The sample size for the survey is 110 . For testing the quality the questionnaire was administered to 11 sample, based on their feedback modification where made in the questionnaire. To analysis the data, the program statistical program for social sciences (SPSS) 19.0 was used. The hypothesis were tested with percentage, one way ANOVA, pearson's correlation.

\section{RESULTS AND DISCUSSION}

Reliability Analysis-Scale (Alpha)

Table - 1: Reliability

\begin{tabular}{|c|c|c|c|c|}
\hline $\begin{array}{c}\text { Dimension } \\
\text { s }\end{array}$ & Mean & $\begin{array}{c}\text { Varianc } \\
\text { e }\end{array}$ & SD & $\begin{array}{c}\text { Cronbach' } \\
\text { s Alpha }\end{array}$ \\
\hline 7 & 102.30 & 111.16 & 11.25 & 0.790 \\
\hline
\end{tabular}

The table reveals that HR Policies questionnaire has adequate reliability (Cronbach's Alpha “r” $=0.790$ ).

Table 2: Show the mean, standard deviation, F-value and p-value of employment policy, training and development, transfers and promotion, compensation, working conditions, industrial relations and employee services and welfare on Age

\section{Hypothesis - 1}

Null Hypothesis H0: There is no significant relationship between employment policy, training and development, transfers and promotion, compensation, working conditions, industrial relations and employee services and welfare on Age

Alternative Hypothesis H1: There is significant relationship between employment policy, training and development, transfers and promotion, compensation, working conditions, industrial relations and employee services and welfare on Age

Table - 2: Difference Between Age and Dimensions of HR Policies

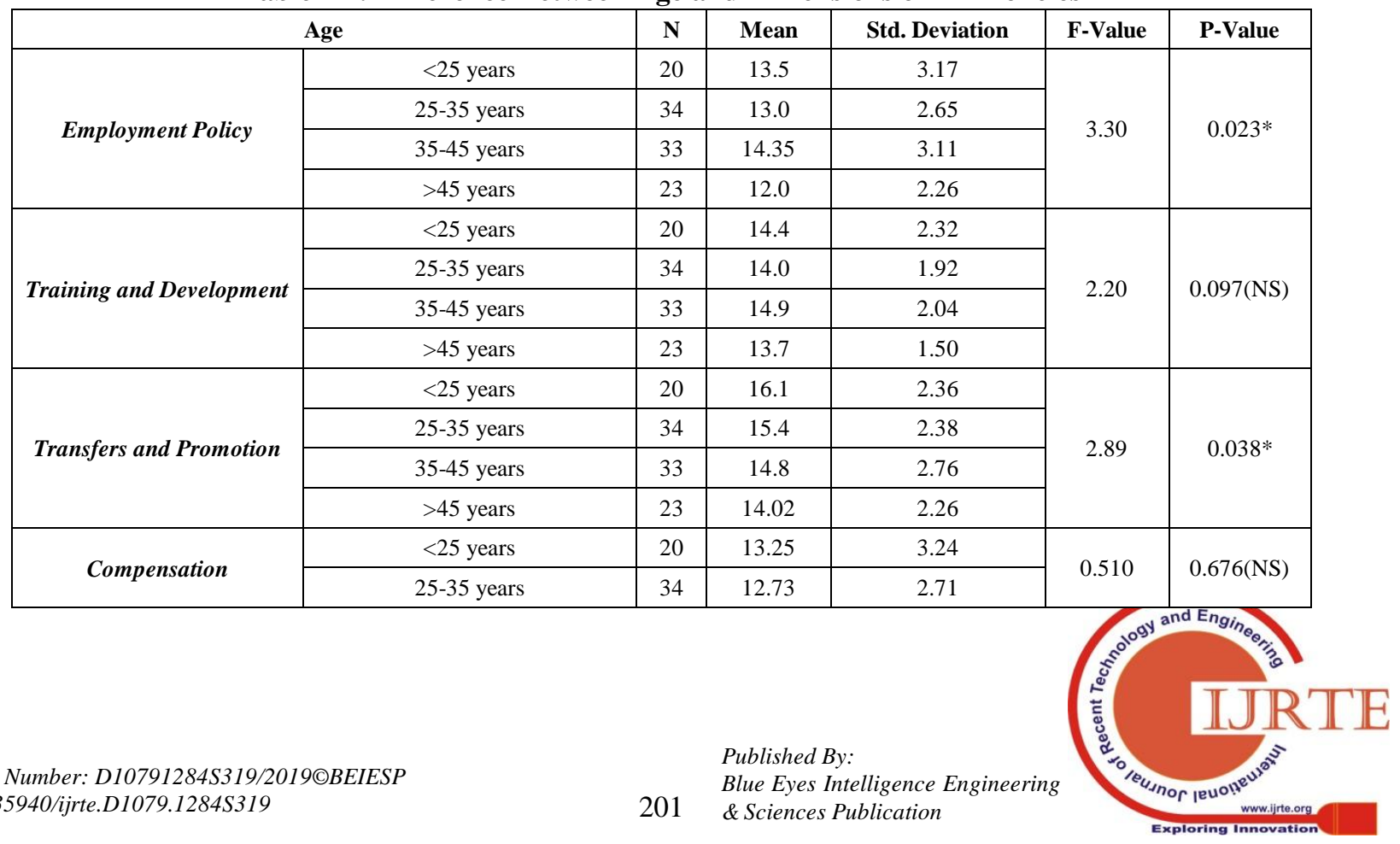




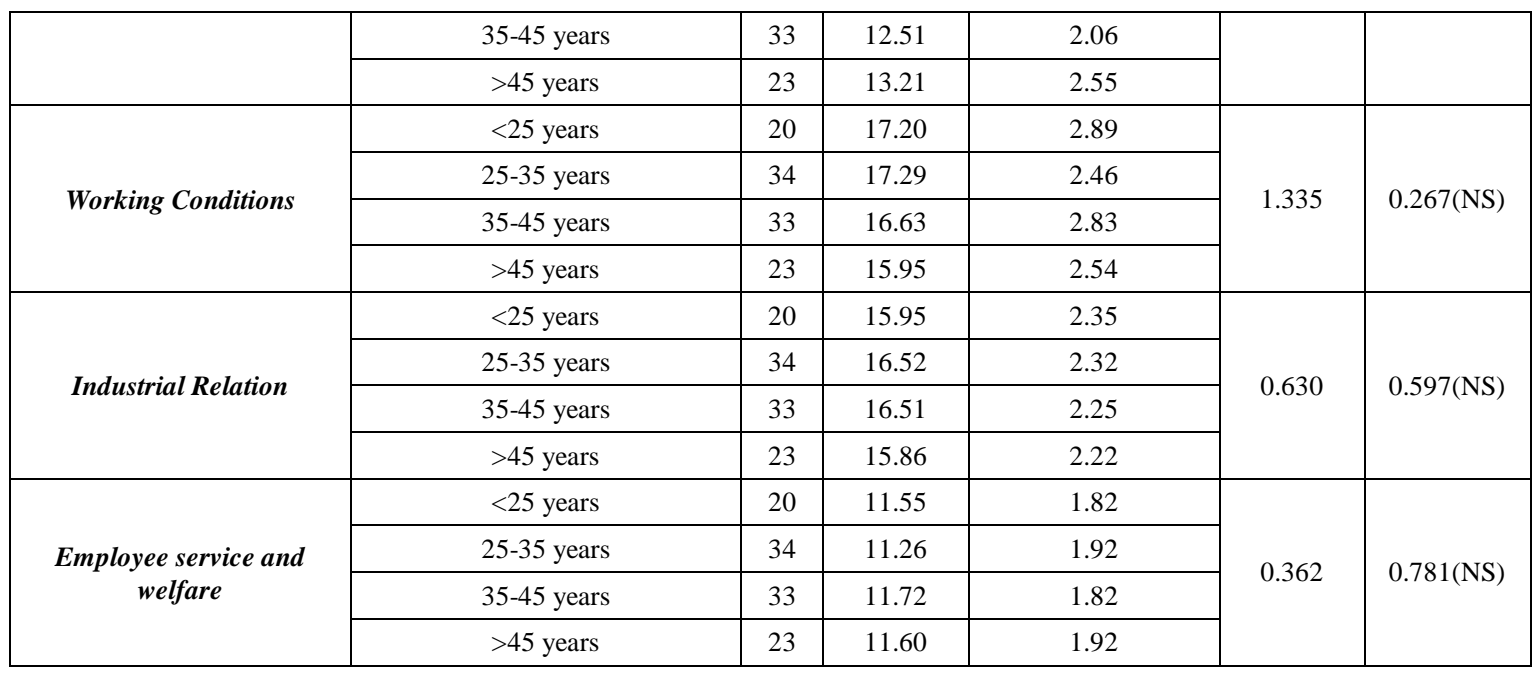

*significant at 0.05 level; **significant at 0.01 level; $N S-$ Not significant

There is a statistically significant difference between the employment policy and age F-value $=3.303$, p-value $=$ $0.023^{*}$ at 0.01 level.

There is a statistically significant difference between the training $\&$ development and age F-value $=2.2074$, p-value $=$ 0.097 at 0.01 level..

There is a statistically significant difference between the training $\&$ performance and age F-value $=2.896$, p-value $=$ 0.038 at 0.05 level.

There is no statistically significant difference between the compensation and age F-value $=0.510, \mathrm{p}$-value $=0.676 \mathrm{at}$ 0.01 level.

There is no statistically significant difference between the working condition and age $\mathrm{F}$-value $=1.335$, p-value $=0.267$ at 0.05 level.

There is no statistically significant difference between the industrial relation and age $\mathrm{F}$-value $=0.630$, $\mathrm{p}$-value $=$

\subsection{7 at 0.01 level.}

There is no statistically significant difference between the employee services \& welfare and age F-value

Table 3: show pearson's product moment correlation of employment policy, training and development, transfers and promotion, compensation, working conditions, industrial relations and employee services and welfare

Hypothesis 5: There is no relationship between independent variable employment policy, training and development, transfers and promotion, compensation, working conditions, industrial relations and employee services and welfare

Hypothesis 6: There is relationship between independent variable between independent variable employment policy, training and development, transfers and promotion, compensation, working conditions, industrial relations and employee services and welfare

Table - 3: Correlation Between Dimensions of HR Policies

\begin{tabular}{|c|c|c|c|c|c|c|c|}
\hline & EP & TD & TP & COM & WC & IR & ESW \\
\hline EP & 1 & & & & & \\
\hline TD & $.370^{*}$ & - & & & & & \\
\hline TP & $-0.306^{* *}$ & $0.304^{* *}$ & - & & & & \\
\hline COM & $0.201^{*}$ & -0.083 & 0.082 & - & & & \\
\hline WC & -0.053 & $0.256^{* *}$ & $0.461^{* *}$ & $0.202^{*}$ & - & & \\
\hline IR & $-0.227^{*}$ & -0.077 & 0.023 & $-0.228^{* *}$ & 0.013 & -- & \\
\hline ESW & -0.163 & -0.110 & $0.249^{* *}$ & 0.128 & $0.398^{* *}$ & -0.147 & - \\
\hline
\end{tabular}

It is found that there is a negative correlation between transfer \& promotion and employment policy ( $\mathrm{r}$-value $=$ -0.306). The correlation co-efficient between transfer \& promotion and employment policy is ( $r$-value $=-0.306$ ) which indicates 30.6 percentage of negative relationship between compensation and training and development is significant at $(\mathrm{p}<0.01)$

It is found that there is a positive correlation between transfer \& promotion and training \& development $(r$-value $=$ $0.304 * *)$. The correlation co-efficient between transfer \& promotion and training \& development is ( $\mathrm{r}$-value $=$ $0.304 * *)$ which indicates 30.4 percentage of positive relationship between transfer \& promotion and training and development is significant at $(\mathrm{p}<0.01)$

It is found that there is a positive correlation between working condition and transfer $\&$ promotion $\mathrm{t}$ ( $\mathrm{r}$-value $=$ $0.461 * *)$. The correlation co-efficient between working condition and transfer \& promotion is ( $r$-value $=0.461 * *)$ which indicates 46.1 percentage of positive relationship between working condition and transfer \& promotion is significant at $(\mathrm{p}<0.01)$ 
It is found that there is a positive correlation between employee service, welfare and working condition ( $r$-value $=$ $0.398 *$ ). The correlation co-efficient between employee service, welfare and working condition is ( $\mathrm{r}$-value = $0.398 * *$ ) which indicates 39.8 percentage of positive relationship between employee service, welfare and working condition is significant at $(\mathrm{p}<0.01)$.

\section{FINDINGS}

\section{Compensation Policy}

$40.8 \%$ of the employees disagree that the compensation provided by the organization is far and adequate.

\section{Working Condition Policy}

$41.9 \%$ of the employees disagree that shift base work is followed in the organization.

\section{Employees service and welfare policy}

$41.9 \%$ of the employees said that group insurance facilities is excellent

\section{Training and Development policy}

$38.1 \%$ of the employees disagree that the organization provides opportunities for career development.

$38.2 \%$ of the employees disagree that the training programme provided by the organization is relevant to the job.

\section{Statistical Findings}

\section{ANOVA}

There is a statistically significant difference between the $0.023 *$ at 0.01 level.

There is a statistically significant difference between the training $\&$ development and age F-value $=2.2074$, p-value $=$ 0.097 at 0.01 level..

There is a statistically significant difference between the training $\&$ performance and age $\mathrm{F}$-value $=2.896$, p-value $=$ 0.038 at 0.05 level.

\section{Correlation}

It is found that there is a positive correlation between transfer $\&$ promotion and training $\&$ development $(\mathrm{r}$-value $=$ $0.304 * *)$. The correlation co-efficient between transfer \& promotion and training \& development is ( $\mathrm{r}$-value $=$ $0.304 * *$ ) which indicates 30.4 percentage of positive relationship between transfer $\&$ promotion and training and development is significant at $(\mathrm{p}<0.01)$

It is found that there is a positive correlation between working condition and transfer $\&$ promotion $\mathrm{t}$ ( $\mathrm{r}$-value $=$ $\left.0.461^{* *}\right)$. The correlation co-efficient between working condition and transfer $\&$ promotion is $(\mathrm{r}$-value $=0.461 * *)$ which indicates 46.1 percentage of positive relationship between working condition and transfer \& promotion is significant at $(\mathrm{p}<0.01)$. employment policy and age F-value $=3.303$, p-value $=$

\section{RECOMMENDATIONS}

\section{A. Compensation}

There should be a just and equitable balance between effort and reward. The compensation should facilitates the employee in maintaining a socially desirable standard of living and should be comparable to the pay for similar work elsewhere. The compensation plan should be easy to understand and simple to operate. The compensation plan should be large enough to encourage the workers. The operation and effectiveness of the compensation policy should be reviewed frequently. Any deficiency in the policies or in its administration should be properly rectified

\section{B. Training and Development Policy}

Training and development programs of the company form a part of the continues process in integrating the needs of a developing organization with the aspirations of individual for fulfillment of career objectives. These activities at perform at two levels, namely the management development at the corporate level and training at the operational level. While the corporate level training programmes are basically helps to improve the managerial effectiveness, the operational level programs are oriented towards technicians, supervisors, engineering/ commercial trainings and such other categories of employee/ trainings. The method and process of training should be related directly to the needs and objectives of the organization.

\section{Employee Service and Welfare}

Organization offer life and health and group insurance programmes to their employees. Most organization offers insurance at a low cost, for below what individual would have to pay to buy insurance by themselves.

\section{CONCLUSION}

From the analysis, it has been found that the most of the employees in the company were satisfied but changes are required and mandatory. According to the changing scenario of HR policies that has a great effect on working of the company as a fresh blood, new idea enters in the company. Selection process is also good and the company's recruitment department is doing well in placing the candidates and filling the job vacancies for all levels of positions. Some of the suggestions were mentioned to enhance the organizational policies, strategies, procedures and process. The training and development procedure should not be lengthy. The working condition procedure should be impartial.

\section{REFERENCES}

1. Armstrong, M., (2008). Strategic Human Resource Management. London: Kogan Ltd .

2. Beardwell, J \& Claydon, T., (2007) Human Resource Management: A Contemporary Approach, 5th Edition Financial Times Management 
3. Biles, George, E. \& Holmberg, Stevan, R. (1980): Strategic Human Resource Planning, Glenn Ridge, New Jersey:

4. Stredwick, J., (2000). An Introduction to Human Resource Management. London: Butterworth- Heinemann.

5. Thomas Horton and Daughters. Bingley, Paul and Niels Westergaard-Nielsen (2004), Personnel Policy and Profit, Journal of Business Research, 57: 557-563.

\section{AUTHORS PROFILE}

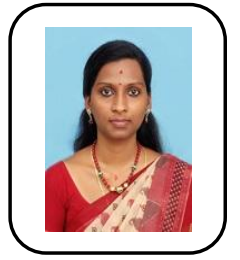

D K Hemamalini, MA(HRM)., MBA., M.Phil., Paper publlished in the Internal Journal of Research in Social Sciences Vol. 8 Issue 6, June 2018,ISSN: 2249-2496 Impact Factor: 7.081 on the topic "Business Strategies in Corporate Social Responsibility". Paper presented and published in National Seminar on "Leadership Lessons from Successful Indian Entrepreneurs" held on 26th September 2018 at Dr Janaki College of Arts and Science for Women on the topic "Enhancing the capacity for workplace Learning and Innovation through Leadership in an Organisation". Undergone NPTEL online certification course (August- September 2018) on the topic "Marketing Research and Analysis". Paper published in the International Journal of Finance and Management Research in the National conference on Issues and Challenges in the New Millennium on Evolving Economy, Accounting and Business Management on the topic "Trends and Perspective of Human Resource Management" organised by Guru Nanak College on 9th January 2019. Paper presented and published in National Conference on "Inclusive Economic and Business growth through Information Technology" held on 25th January 2019 Aksheyaa College of Arts and Science , Kanchipuram, on the topic "Technology and Evironmental Protection in Global Companies"..

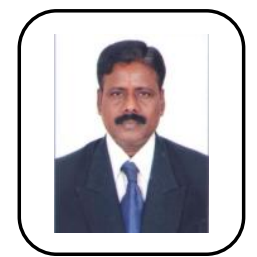

Dr. Sundharavadivel" is a "Professor" at Department of Adult \& Continuing Education, University of Madras with more than 15 years of Experience in the field of Adult and Continuing Education. The author is a rank holder in MA (Andragogy), did Ph.D. in Vocational Education from the University of Madras. $\mathrm{He}$ did his M.L.M, MBA and M.Phil (Entrepreneurship) from M.K. University. The author completed M.S.W, M.Sc. (Yoga) from Annamalai University and PGDHRM from Pondicherry University. The author served as programme officer NSS from 2005 to 2010 and has presented papers in National and International seminar, Conferences and workshops. The author has also completed M.COM (Education Management). The author has received "Aasiriyar Semmal" award from Thamizhaga Institute of Educational Research and Advancement (TIERA) on teacher's day, September 5th 2019 and "Best professor" award from ESN Publications on 28th September 2019. He has published in the reputed and UGC approved journals. 